individual a law-abiding citizen. Presumably such a man may be trained to lawlessness also. He has the capacity for both. In which case the special "proclivity" or "diathesis" of criminals can be nothing more than mere stupidity, mere incapacity to be trained. As expressed by Sir Bryan Donkin :- -

"They are, it seems, innately unable to acquire the complex of characters which are essential to the average man, and, according to their surroundings, they follow the path of least resistance. This path is more often than not, but by no means always, the path of unsocial or criminal action" (p. 7).

In conclusion Dr. Goring states :-

"Our tables of figures speak for themselves, we have said; but we do not claim that they utter the last word. ... A long intimacy with the material discussed in the present Report leads us to believe that better material could, with the experience now attained, be procured; but we are convinced that, at least to a first approximation, our data represent the fundamental interrelationships of criminality" (p. 373). In a note he adds:--" The inquiry, which of all others is most urgently needed, must not be limited to an examination of prisoners and their official records; but must extend beyond the prison walls, and into the homes and haunts of the offenders when at large; and into that wide and most interesting field of research where the experiments of the modern reformatory system are dealing with the child-criminal of the race" (p. 373).

\section{SIR JOHN MURRAY, K.C.B., F.R.S.}

THE tragic accident by which Sir John Murray lost his life on March 16 has deprived the world of one of the foremost naturalists of the day, and has sent a thrill of sorrow through the hearts of all who knew him. Though he had passed the allotted span of threescore years and ten, he still so abounded in youthful spirits and enthusiasm, was so active alike in body and mind, so full of work and of plans for further enterprise, that it is hard to believe that a career so distinguished in its past and bearing such continued promise for the future, has been suddenly brought to a close.

Of Scottish parentage, he was borm in Canada in $\mathrm{I} 84 \mathrm{I}$, and received there the early part of his education. But in his youth he came to Edinburgh, and at the University there, under J. $\mathrm{H}$. Balfour, P. G. Tait, G. J. Allman, and A. C. Brown, he received the training in physical and natural science that formed the groundwork of his lifelong labours. He soon showed the bent of his disposition towards marine studies, and at the same time his love of personal adventure, by taking, in the year 1868 , a voyage in a Peterhead whaler to Spitsbergen and the Arctic seas. In the same year there began that series of pioneering cruises in the Lightning and Porcupine, by which, during the summers of 1868 , I869, and I870, Wyville Thomson and W. B. Carpenter obtained so much new information regarding the distribution of life in the ocean. Deep-sea exploration became then a leading preoccupation among the naturalists of this country.

No. 23I7, voL. 93]
Eventually the general interest in this subject found vent in an application to the Government for a vessel and funds to prosecute the study of the ocean all over the globe. The memorable expedition of the Challenger was accordingly organised, which lasted from 1873 to 1876 . Wyville Thomson, who had been elected in 1870 to the Chair of Natural History in the University of Edinburgh, was appointed director of the civilian scientific staff of the expedition. Recognising the brilliant promise of John Murray, he chose him to be one of the three naturalists on his staff. To this momentous choice the young aspirant to scientific distinction owed the opening which led to all the varied labours which have made his name so widely known.

When Wyville Thomson died in 1882, Murray, who had proved his remarkable qualities during the course of the expedition, was charged with the editorship of the scientific results of the cruises of the Challenger. This was a task the greatness of which is probably not generally appreciated. No ordinary skill, knowledge, tact, and patience were required to allocate the vast pile of collections to the different specialists all over the globe, to keep these writers up to their engagements, and, within reasonable limits of time, to see that the printers and engravers were supplied with material, to supervise the masses of proof-sheets, and, by no means least of all, to battle with an unsympathetic Treasury that grudged the heavy expense necessarily required for the publication of the work of the most completely organised expedition that had ever sailed the seas. Year after year the labours of the editor went on, until some fifty massive quarto volumes were issued. That Murray should have emerged with triumphant success from so prolonged and so trying an ordeal was a striking proof of the strength of his character and the vigour of his scientific enthusiasm.

Besides taking an active part in the dredging and the general biological work of the expedition, Murray specially devoted his attention to the working out of certain parts of the materials obtained. He was more particularly interested in the investigation of the deposits that are accumulating on the floor of the ocean. The ample store of materials which he succeeded in gathering together was subsequently carefully studied by him in concert with the late Prof. Renard, of the University of Ghent, and the conjoint work of the two observers was published as one of the thick quartos of the Challenger Reports. This monumental volume possesses a high scientific value, coupled with the historical interest that it gave to the world the first detailed revelation of the nature and distribution of the deposits that are gathering on the floor of the deep sea, and the impressively slow rate at which some of these deposits are being formed.

A further inquiry arising out of the operations of the Challenger expedition was the question of the origin of coral islands. The fascinating explanation of these islands proposed by Darwin had been generally accepted by men of science, though 
some doubts had been thrown upon its universal application. Murray, who was not always disposed to accept the conclusions of his predecessors without subjecting them to rigorous investigation, was led to entertain more than doubts as to the general applicability of Darwin's theory. He ultimately came to the conclusion that the extensive oceanic submergence which the great naturalist's explanation demanded could not be proved from coral reefs. He propounded another view in which he was supported by the late Alexander Agassiz, who undertook many cruises over different oceans, visiting most of the coral regions and obtaining an unrivalled acquaintance with their various features. According to this view, coral reefs have grown up on submarine volcanic peaks, which in many cases have been covered with thick accumulations of calcareous organisms, so as to be brought up within the limits of the growth of reef-building corals. The problem probably cannot be solved by any one universally applicable hypothesis. Whether or not subsidence has played a part in the formation of coral islands there can be no doubt, from the full narratives of Agassiz, that proofs of elevation are conspicuously obvious in many of the groups of these islands.

Sir John Murray's latest expedition took place only four years ago, when at his request the Norwegian Government lent him a surveying vessel, the Michael Sars, together with its scientific staff, for a summer cruise of four months in the North Atlantic Ocean, while he himself undertook to defray all the other expenses. The cruise proved highly successful, but perhaps its most important result has been the preparation and publication of a work on the "Depths of the Ocean," the joint production of Sir John himself and Dr. Johan Hjort. This handsome volume is undoubtedly the best and most authoritative treatise on the subject to which it is devoted. It places clearly before the reader the main incidents in the history of the investigation of the deep sea, and it describes the methods of research and the general scientific results obtained, with fresh illustrations from the experience gained in the cruise of the Michael Sars. Sir John had already been recognised as one of the chief founders of the modern science of Oceanography, and in this admirable volume he has left what will long be the leading manual on the subject.

It was at his instance that upwards of five-andtwenty years ago the British Government was led to annex Christmas Island, a lonely volcanic peak in the Indian Ocean, which seemed never to have been disturbed by man. He sent out some competent observers to study its geology and natural history, and these visitors found it to be rich in phosphatic deposits. He thereupon formed a company, which obtained a concession to work these accumulations. With the wealth that accrued to him from this source. he has been a generous supporter of scientific investigation in many directions. One of the undertakings which he set on foot and financed was a thorough bathymetrical survey of the freshwater lochs of Scotland by practised observers. The results of this investigation have been published in a series of six volumes. There is probably no other country of which the depths and other features of its lakes have been so fully made known.

Sir John Murray's devotion to science and his sagacity in following out the branches of inquiry which he resolved to pursue were not more conspicuous than his warm sympathy with every line of investigation that seemed to promise further discoveries. He was an eminently broad-minded naturalist to whom the whole wide domain of Nature was of interest. Full of originality and suggestiveness, he not only struck out into new paths for himself, but pointed them out to others, especially to younger men, whom he encouraged and assisted. His genial nature, his sense of humour, his generous helpfulness, and a certain delightful boyishness which he retained to the last endeared him to a wide circle of friends who will long miss his kindly and cheery presence.

Arch. Geikie.

\section{PROF. E. S. HOLDEN.}

DROF HOLDEN, whose death was aniounced with regret in our last issue, was better known to the astronomers of the last generation than the present. He will be remembered as one who, by his energy and position, encouraged the enterprise and activity that have characterised the development of astronomical research in the United States. It was his fortune, thirty years ago, to be placed at the head of the Lick Observatory, the optical equipment of which was then superior to any that existed. Also the position of the observatory had been selected with care and at considerable expense. He had to construct a programme and to pursue it with such ardour and success that the results should justify the costly erection of the gigantic refractor in a spot remote and difficult of access. In his work as a pioneer he had little to guide him, for though telescopes had gradually increased in power, they had been employed mainly in doing more perfectly what small telescopes had attempted. We may claim that the Lick telescope in his hands was a success. It is, of course, difficult to separate the work of a director from that of the subordinates selected to carry it into effect. 'The one provides a programme, but the performance must be largely in the hands of the lieutenants.

Prof. Holden was fortunate in the choice of his assistants and in the apportionment of their work. His assistants all increased their reputation under his direction, and demonstrated the capacity of the instrument entrusted to their charge. Barnard added an inner satellite to the Jovian system.; Burnham's double-star work remains unsurpassed; Keeler's successful demonstration of the meteoritic constitution of Saturn's rings and his determination of the motion in the line of sight of the planetary nebulæ would have made the reputation of any observatory. Naturally some credit for these successes attaches to Prof. Holden. But his 